\title{
CORPORATE TAX REPORTING: EFFECTIVE TAX RATE OF SERBIAN PUBLIC ENTITIES
}

\author{
Vule Mizdraković ${ }^{1 *}$, \\ Maja Kljajićn ${ }^{1,2}$, \\ Marija Slavković ${ }^{3}$ \\ ${ }^{1}$ Singidunum University, \\ Belgrade, Serbia \\ ${ }^{2} \mathrm{PhD}$ candidate \\ Singidunum University, \\ Belgrade, Serbia \\ ${ }^{3}$ MS Finance \& Accounting, \\ Belgrade
}

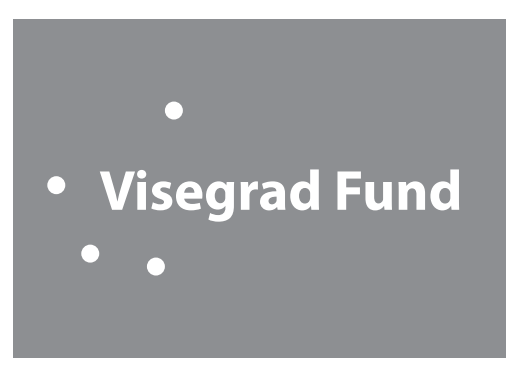

\begin{abstract}
:
The main purpose of this paper is to analyze the correlation between financial (accounting) result in income statement and tax result in tax report. Calculation of corporate income tax expense is a complex procedure which requires the use of legal tax regulation. As a result, legal entities could report profit in their financial statements, and do not have income tax expense at the same time. Research sample consists of randomly selected 322 business entities and their annual reports from Belgrade Stock Exchange for 2017. The results of the research show that average effective tax rate of sample entities is app. $12 \%$, while median is app. $9 \%$.
\end{abstract}

Keywords:

corporate tax, financial reporting, effective tax rate, loss and profit before tax.

\section{INTRODUCTION}

The structure of the state's tax system is an important determinant when it comes to the economic performance of a state. Each tax system has three basic objects of taxation, namely: consumption, income and property (The Government of the Republic of Serbia, 2020), (Aleksic, 2019). When it comes to consumption, there are the following taxes: VAT (as a general consumption tax), excise duty and tax on non-life insurance premiums. On the other hand, corporate income tax and personal income tax are taxes related to income. When it comes to property, the following taxes are distinguished: property tax; inheritance and gift tax; tax on the transfer of absolute rights; and taxes on the use, possession and carrying of goods. Research subject of this paper is the corporate income tax of business entities and differences between financial result disclosed in income statement and tax result disclosed in tax statement. Although the corporate tax has a significant impact on a country's economy, it brings in a relatively low amount of tax revenue for most governments. The paper will present the procedure for calculating corporate income tax in the Republic of Serbia, and the results of the research will show the average effective profit tax rate of the sampled public companies.

\section{CHARACTERISTICS OF CORPORATE INCOME TAX CALCULATION IN SERBIA}

According to the Law on Corporate Income Tax, a taxpayer is an entity established for the purpose of performing different activities and gaining profit. A taxpayer is also a cooperative that generates income by selling products on the market or performing services for a fee. 
According to this law, taxpayer is also another legal entity that is not established to gain profit, but to achieve other goals, but only if it earns profit by producing and selling products or if it provides services for a fee. The Law on Corporate Income Tax defines a wide range of legal entities that are obliged to pay corporate income tax (Official Gazette of the Republic of Serbia, 2019).

\subsection{Calculation of the tax base and tax rate}

Taxable profit is determined in the tax statement by adjusting the taxpayer's financial result disclosed in the income statement. That result is calculated in accordance with International Accounting Standards (IAS), i.e. International Financial Reporting Standards (IFRS), and International Financial Reporting Standard for Small and Medium Legal Entities (IFRS) for SMEs) and regulations governing accounting, in the manner prescribed by the Law on Accounting. Taxable profit of a taxpayer who, according to the accounting regulations, does not apply IAS (i.e. IFRS and IFRS for SMEs), is determined in the tax balance by adjusting the taxpayer's profit, calculated in accordance with the method of recognition, measurement and assessment of income and expenses prescribed by the Minister of Finance.

The taxpayer is obliged to calculate and pay income tax disclosed in the tax return for reporting period. However, the tax is paid in advance according to the amount of tax from previous period. Therefore, if the taxpayer paid less than he/she is obliged to pay according to the amount disclosed in the tax return, he is obliged to pay the difference no later than the filing date of the tax return (and submit a proof of payment of the tax difference).
Sometimes taxpayers can pay more than they are later obliged, therefore the overpaid tax will be used as an asset for the next tax period; or it will be refunded within 30 days from the date of receipt.

The taxpayer is obliged to submit tax return to the tax authority in charge, for the period for which the tax is determined. The tax return is submitted within 180 days from the expiration of the period for which the tax is determined. All states impose income taxes, but rates and bases vary greatly between them. There are numerous implications of high or low income tax rate. Namely, income tax reduces the rate of return on income tax after tax, thus increasing the cost of capital, which leads to lower levels of investment and economic production. In addition, high income tax rate leads to lower wages, lower investment returns and higher final prices of goods and services. In the case of the Republic of Serbia, the corporate income tax rate is proportional and uniform and amounts to $15 \%$. The tax period for which income tax is calculated is a business year.

The following table will show the trends in income tax rate in the period 2010-2019.

Table 1. Trends in income tax rate in the period 2010-2019

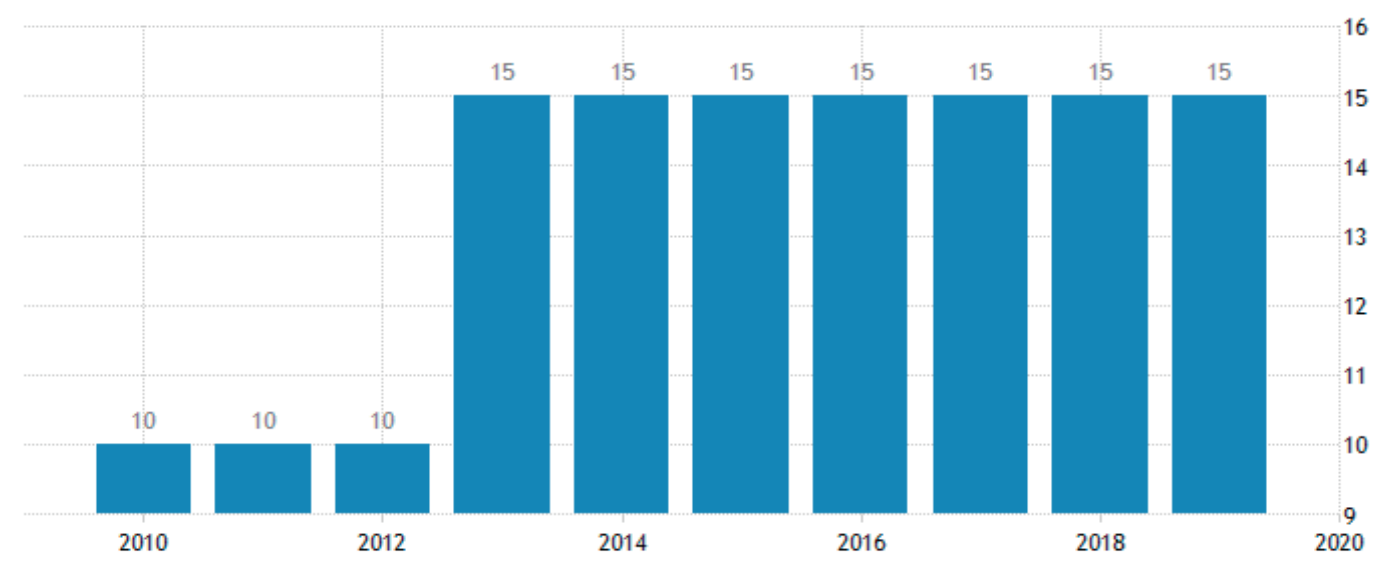

Source: (Trading Economics, 2020)

When it comes to other countries, income tax rates differ among them and each one is determined based on the power of economy and fiscal politics of the country.
As a result, some countries have $0 \%$ income tax rate, while in others legal entities will have to reserve one third of their earned profits to pay income tax. 
Table 2. Corporate income tax rates by countries and territories

\begin{tabular}{|c|c|}
\hline Corporate tax rates & Countries and territories \\
\hline $0 \%$ & $\begin{array}{l}\text { Anguilla, Bahamas, British Virgin Islands, Bahrain, Latvia, Bermuda, Isle of Man, Cayman Islands, Georgia, } \\
\text { Guernsey, Jersey, Kuwait, Latvia, Saint Kitts and Nevis, Sark, United Arab Emirates }\end{array}$ \\
\hline $5 \%$ & Saudi Arabia \\
\hline $8 \%$ & Hong Kong ${ }^{1}$, Maldives ${ }^{2}$ \\
\hline $9 \%$ & Hungary, Montenegro \\
\hline $10 \%$ & $\begin{array}{l}\text { Andorra, Bosnia and Herzegovina, Bulgaria, Gibraltar, Morocco }{ }^{3} \text {, Mongolia, North Macedonia, Paraguay, } \\
\text { Qatar, U.S. Virgin Islands }\end{array}$ \\
\hline $12 \%$ & Macau, Moldova, Canada ${ }^{4}$ Croatia $^{5}$ Uzbekistan $^{6}$ \\
\hline $13 \%$ & Cyprus, Ireland, Liechtenstein, Tajikistan ${ }^{7}$ \\
\hline $15 \%$ & Iraq, Lithuania, Mauritius, Oman, Palestine, American Samoa ${ }^{8}$, France ${ }^{9}$, Sri Lanka ${ }^{10}$ \\
\hline $16 \%$ & Romania \\
\hline $17 \%$ & Lebanon, San Marino, Singapore, Azores, India ${ }^{11}$ \\
\hline $18 \%$ & Belarus, Switzerland, Ukraine, Malaysia ${ }^{12}$ \\
\hline $19 \%$ & Czech Republic, Poland, Slovenia, United Kingdom,Algeria ${ }^{13}$ \\
\hline $20 \%$ & $\begin{array}{l}\text { Afghanistan, Armenia, Azerbaijan, Brunei, Cambodia, Fiji, Finland, Iceland, Jordan, Puerto Rico, Russia, } \\
\text { Taiwan, Thailand, Vietnam, Yemen, Estonia, Cook Islands }{ }^{14} \text {, Kazakhstan, Netherlands }{ }^{15}\end{array}$ \\
\hline $21 \%$ & Portugal, Sweden, United States ${ }^{16}$ \\
\hline $22 \%$ & Botswana, Curacao, Denmark, Slovakia, Syria, Turkey \\
\hline $23 \%$ & Israel, Norway, Egypt ${ }^{17}$ \\
\hline $24 \%$ & South Korea \\
\hline $25 \%$ & $\begin{array}{l}\text { Aruba, Austria, Cape Verde, Dominica, Ecuador, Guatemala, Indonesia, Iran, North Korea, Liberia, Panama, } \\
\text { Senegal, Trinidad and Tobago, Uruguay, China, } \mathrm{Nepal}^{18}, \mathrm{Spain}^{19}\end{array}$ \\
\hline $26 \%$ & Bhutan, Falkland Islands \\
\hline $27 \%$ & Chile, Dominican Republic \\
\hline $28 \%$ & Burkina Faso, Eswatini (Swaziland), Greece, Italy, Monaco, New Zealand, South Africa \\
\hline $29 \%$ & Bolivia, Luxembourg \\
\hline $30 \%$ & $\begin{array}{l}\text { Angola, Argentina, Belgium, Central African Republic, Cook Islands, Congo, Costa Rica, Cuba, El Salvador, } \\
\text { Germany, Guyana, Haiti, Japan, Kenya, Mexico, New Caledonia, Nigeria, Peru, Philippines, Rwanda, } \\
\text { Tanzania, Tunisia, Uganda, Australia }{ }^{20}, \text { Seychelles }^{21}\end{array}$ \\
\hline $31 \%$ & Gambia, Pakistan \\
\hline $32 \%$ & Cameroon, Namibia \\
\hline $33 \%$ & Colombia, Jamaica ${ }^{22}$ \\
\hline $34 \%$ & Brazil, Venezuela \\
\hline $35 \%$ & Bangladesh, Benin, Burundi, DR Congo, Gabon, Malta, Zambia, Zimbabwe \\
\hline $36 \%$ & Suriname \\
\hline
\end{tabular}

Source: (Dharmapala \& Hines, 2009), (Bunn \& Asen, 2019), (Ministry of Finance - Estonian Tax and Customs Board, 2019), (Deloitte, 2020), (KPMG, 2020)

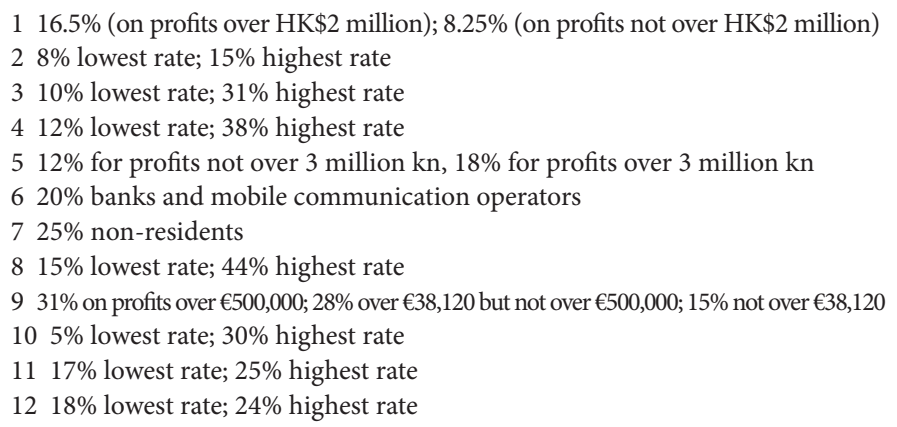




\subsection{Adjustments of expenses}

The amounts of expenses disclosed in income statement will not be recognized in tax report, in following cases:

- undocumented costs;

- value adjustments of individual receivables from the person to whom it is owed at the same time, up to the amount of the obligation to that person;

- gifts and donations given to political organizations;

- gifts whose recipient is a related party (entity);

- - interest costs due to late payment of taxes, contributions and other public duties;

- costs of the procedure of forced collection of taxes and other debts, costs of tax misdemeanor proceedings and other misdemeanor proceedings conducted before the competent authority;

- fines imposed by the authority, contractual penalties and other penalties;

- default interest between related parties;

- costs that were not incurred for the purpose of performing business activities, unless otherwise regulated by this Law.

The following is recognized as an expense in tax report (even if not recognized in income statement):

- cost of materials and cost of goods sold are recognized in amounts calculated using the weighted average cost method or the FIFO method;

- salary costs, i.e. salaries, are recognized in the amount calculated at the expense of operating expenses;

- employee benefits that are considered earnings, including benefits that are not subject to payroll taxes up to the amount prescribed by law, are recognized as an expense in the tax balance in the tax period in which they were paid or realized;

- accrued severance and cash benefits to an employee in case of retirement and termination of employment on another basis, are recognized as an expense in the tax report in the tax period in which they are paid;

- depreciation of fixed assets is recognized as an expense in the amount and in the manner determined by law

- loss from the sale of individual receivables in the amount stated in the income statement, in the tax period in which the sale of these receivables was made.

- total accrued interest, excluding interest due to late payment of taxes, contributions and other public duties;

- taxes, contributions, fees and other public duties that do not depend on business results, which are paid in the tax period;
- long-term provisions for the restoration of natural resources, in the amount of costs within the warranty period and retained collateral and deposits, as well as other mandatory long-term provisions;

- other long-term provisions that meet the conditions for recognition in accordance with IAS, ie IFRS and IFRS for SMEs, in the amount of used amounts of these provisions in the tax period;

- impairment of assets, which is determined as the difference between the net present value of assets and its estimated recoverable amount, but are recognized in the tax period in which the asset is disposed of or used;

- double amount of costs that are directly related to research and development performed by the taxpayer.

However, some expenses could be recognized in tax report, but only in the proscribed amount. For example, following expenses are recognised in the total amount of up to $5 \%$ of the total revenues:

- expenditures for health, educational, scientific, humanitarian, religious and sports purposes, environmental protection, as well as benefits made to institutions or providers of social protection services;

- expenditures for humanitarian aid, i.e. elimination of consequences incurred in case of emergency;

- expenditures for investments in the field of culture, including cinematographic activity.

On the other hand, membership fees to chambers, federations and associations are recognized as an expense in the tax report up to a maximum of $0.1 \%$ of total income. Also, representation expenses are recognized as an expense in the amount of up to $0.5 \%$ of total income.

\subsection{Adjustments of revenues}

Revenues earned in the form of dividends and profit share by a resident taxpayer are not included in the tax base. Revenue earned by a resident taxpayer from interest on debt securities issued by, the Republic, an autonomous province, a local self-government unit or the National Bank of Serbia; is not included in the tax base. In addition, revenue that a resident taxpayer, established in accordance with the regulations governing investment funds, realizes on the basis of the alienation of property is not included in the tax base. Revenue arising from unused long-term provisions that were not recognized as an expense in the tax period, in which they are recognized, is not included in the tax base in the tax period in which they are reported. 


\section{EFFECTIVE TAX RATE}

The effective tax rate represents the actual tax liability of the corporate taxpayer. This financial indicator is calculated by dividing the calculated income tax and profit before tax. It is important to note that in entities with a negative amount of profit before tax (loss before tax), it is not possible to calculate the effective tax rate (Knezevic, Stanisic, \& Mizdrakovic, 2019). The effective tax rate may be higher or lower than the legal (nominal) corporate income tax rate. The difference may arise due to various adjustments, previously mentioned, to the financial result prescribed by the Law on Corporate Income Tax in order to arrive at the amount of taxable profit.

The effective tax rate is an indicator of the company's success in managing the costs of corporate income tax. In order for a company to achieve an optimal effective tax rate, it needs a tax strategy that will be fully in line with its business goals and plans, as well as with the requirements of legal regulations (PwC Serbia, 2020).

\section{RESEARCH METHODOLOGY AND RESULTS}

For the purposes of this paper, 322 business entities and their annual reports from Belgrade Stock Exchange (BELEX) were randomly selected. It can be assumed that public companies show higher responsibility in terms of tax settlement, including profit tax, than other entities. Therefore, this research will be focused on their business practice. Financial reports were collected from the database of the Serbian Business Registers Agency (SBRA, 2018)for 2017 as a reporting period. The research analyzed the information presented in income statement, with following statement items in focus: profit before tax, loss before tax, tax expense for the period and the calculated effective tax rate.

As previously mentioned, the financial (accounting) result from the income statement represents the basis for calculating the tax amount in the tax balance. The results of the research show that the largest number of companies has a positive financial result, about $62 \%$ of the total number of sampled companies. On the other hand, there are 123 companies with a loss before tax, i.e. companies that have higher expenses than income.

The total amount of profit before taxes of these companies is $€ 482,635,170$. Based on that, it can be assumed that the tax authorities will collect a total of 72,395,276 euros. However, as mentioned above, due to the adjustment of revenues and expenses in the tax balance, the tax base will probably not be equal to financial result, as well as the amount of collected income tax. The results show that total amount of tax expense of sample companies equals to $€ 64,302,251$, which is less than expected amount of collected tax by app. $11 \%$. The following table will show the number of companies in relation to the loss / profit before tax.

Table 3. Profit / Loss before taxes of sampled companies

\begin{tabular}{|lcc|}
\hline & Number of Entities & Percentage \\
\hline Loss before Tax & 123 & $38,20 \%$ \\
\hline Profit before Tax & 199 & $61,80 \%$ \\
\hline Total & 322 & $100 \%$ \\
\hline
\end{tabular}

The table below shows the companies from the sample according to whether they have a positive or negative financial (accounting) result in relation to a positive or negative tax result. The basic idea is to show the number of companies that made a loss in the income statement, but after adjustments of revenues and expenses in the tax report recorded a positive tax result, i.e. were obliged to pay a certain amount of income tax. There are only 6 such companies (almost $5 \%$ of the total sample). On the other hand, there is far higher number of companies that made a profit before tax in the income statement, but avoided paying income tax after correcting income and expenses in the tax report. There were about $40 \%$ of such companies in the total sample.

Table 4. Connection between financial and tax result of sample entities

\begin{tabular}{|lcc|}
\hline & $\begin{array}{c}\text { Number of } \\
\text { Entities }\end{array}$ & $\begin{array}{l}\text { Out of total number } \\
\text { of entities with } \\
\text { negative/positive } \\
\text { financial resu }\end{array}$ \\
\hline $\begin{array}{l}\text { Entities with negative } \\
\text { financial result and } \\
\text { positive tax result }\end{array}$ & 6 & $4,88 \%$ \\
\hline $\begin{array}{l}\text { Entities with positive } \\
\text { financial result and } \\
\text { negative tax result }\end{array}$ & 80 & $40,20 \%$ \\
\hline
\end{tabular}

In the case of the first group of companies, the previous part of the paper lists expenses that are not recognized, or are recognized in a partial amount, which leads to an increase in the tax base for the reported amounts. That leads to the situation that after all adjustments a certain company will report tax profit and a tax expense, although financial result in income statement is negative.

When it comes to the second group of companies, it can be noticed that there are 80 companies $(40.20 \%)$ that reported profit before tax in income statement, but do not have the obligation to pay income tax. Namely, adjustments lead to a reduction of the tax base, because some revenues are not tax recognized. 
Also, companies that have had a tax loss in some of the previous five years (reporting periods), and have a reported profit in current reporting period, can use that tax loss to reduce the tax base. Therefore, total loss from previous years reduces the entire corporate income tax base and tax expense will be equal to zero. Also, it is necessary to remind that the management of companies using the techniques of positive and negative creative accounting can show the profit before tax in the income statement, in order to achieve the planned goals, while avoiding paying taxes. In any case, the percentage of these companies in relation to the total number of sampled companies is rather high (especially if we take into account the number of companies that made a profit before tax, 199 entities).

Finally, the table below shows the results of descriptive statistics when it comes to the effective tax rate of the companies in the sample.

Table 5. Data on the calculated effective tax rate of the sampled companies

$\begin{array}{ccccccccccc}\text { Mean } & \begin{array}{c}\text { Standard } \\ \text { Error }\end{array} & \text { Median } & \begin{array}{c}\text { Standard } \\ \text { Deviation }\end{array} & \begin{array}{c}\text { Sample } \\ \text { Variance }\end{array} & \text { Kurtosis } & \text { Skewness } & \text { Range } & \text { Min } & \text { Max } \\ 0,1209 & 0,0125 & 0,0866 & 0,1763 & 0,0311 & 17,9189 & 3,3869 & 1,4222 & 0 & 1,4222\end{array}$

It can be noticed that the average value of the effective tax rate is $12.1 \%$ and that it is lower compared to the nominal tax rate of $15 \%$. This means that the obligation to pay corporate income tax from the sample is on average lower by almost $3 \%$ compared to the nominal one. However, the median value of effective income tax rate could be used to present the situation more realistically. Namely, this number divides the sample exactly in half and indicates that in this case there are more companies above the middle. The reason for that are companies outliers with very high profit tax rates (maximum value of tax rate is $142.22 \%$, but the absolute value of tax is very low). Therefore, if median is chosen as the average value, it can be concluded that the companies from the sample have an effective tax rate averaging $8.66 \%$.

\section{CONCLUSION}

The main purpose of this paper is to point out the specifics of the tax system of the Republic of Serbia. For the purposes of the research, 322 business entities whose shares are listed on Belgrade Stock Exchange in the Republic of Serbia for 2017 were randomly selected. Research results show that the largest number of companies has a positive financial result, about $62 \%$ of the total number of sampled companies, while the remaining (app. 38\%) are companies with a loss before tax. On the other hand, the results of the research show that there are a number of companies that have a profit before tax, but do not have the obligation to pay taxes and vice versa. When it comes to effective tax rate, it was noticed that it amounts to $12.1 \%$, which is a lower rate compared to the nominal one. However, if the median for the average value is taken into account, the results of the research show that sampled entities in the territory of Serbia have an effective tax rate of $8.66 \%$ on average.
Future research could be focused on more detailed analysis of the taxpayer's profile in terms of its size, legal form, total value of assets, age of the company and other characteristics.

\section{ACKNOWLEDGMENT}

This paper is part of the project No. 22010083 entitled "Experience sharing of Visegrad countries to tax avoid activity" financed by the International Visegrad Fund.

\section{LITERATURE}

Aleksic, V. (2019). Poreski sistem u Srbiji i promene poreskog sistema u skladu sa tendencijama u svetu. Kultura polisa, 39(1), 525-538.

Bunn, D., \& Asen, E. (2019). International tax competitiveness Index 2019. 1-63. The Tax Foundation.

Dharmapala, D., \& Hines, J. (2009). Which countries become tax havens? Journal of Public Economics, 93(9-10), 1058-1068.

Deloitte. (2020). International Tax. Retrieved from Corporate Income Tax: https://www2.deloitte.com/content/dam/ Deloitte/global/Documents/Tax/dttl-tax-corporatetax-rates.pdf

Knezevic, G., Stanisic, N., \& Mizdrakovic, V. (2019). Analiza finansijskih izveštaja . Beograd: Univerzitet Singidunum.

KPMG. (2020). Tax. Retrieved from Corporate tax rates table : https://home.kpmg/xx/en/home/services/tax/tax-toolsand-resources/tax-rates-online/corporate-tax-rates-table.html

Ministry of Finance - Estonian Tax and Customs Board. (2019). List of territories which are not regarded as low tax rate territories. Retrieved from https://www.emta. ee/eng/business-client/income-expenses-supply-profit/ taxation-income-non-residents/list-territories-which 
Official Gazette of the Republic of Serbia No. 76/91, 41/92 other low, 18/93, 22/93 - corr., 37/93, 67/93, 45/94, 42/98 and 54/99). (2020). Law on public revenues and public expenditures.

Official Gazette of the Republic of Serbia. (2019). The Law on Corporate Income Taxbr. 25/2001, 80/2002, 80/2002 - other low, 43/2003, 84/2004, 18/2010, 101/2011, 119/2012, 47/2013, 108/2013, 68/2014 - other low, 142/2014, 91/2015 - authentic interpretation, 112/2015, 113/2017, 95/2018 and 86/2019). Belgrade.

PwC Serbia. (2020). Tax services . Retrieved from Optimizing effective tax rate : https://www.pwc.rs/en/services/tax/ optimizing-effective-tax-rate.html
SBRA. (2018). Criteria for Classification and Limit Values for 2018. Retrieved 3 15, 2019, from The Serbian Business Registers Agency (SBRA): http://www.apr.gov.rs/

Trading Economics . (2020). Corporate Tax Rate . Retrieved from Serbia Corporate Tax Rate 2003-2019: https:// tradingeconomics.com/serbia/corporate-tax-rate

The Goverment of the Republic of Serbia. (2020). In the service of citizens. Retrieved from Tax system of the Republic of Serbia: https://www.srbija.gov.rs/tekst/329944/poreskisistem.php 